173 MARIA DAMKJÆR

Post.doc., Institut for Engelsk, Germansk og Romansk, Københavns Universitet

\title{
AFBRYDELSENS KRONOTOPI I BRITISK LITTERATUR, 1840-1870
}

Fru Gibson havde irettesat [Molly and Cynthia] et par gange for deres muntre støj, der forhindrede hende i at tælle stingene i hendes broderi. [...] 'Hr. Roger Hamley' blev meldt i døren. 'Hvor irriterende!' sagde fru Gibson, næsten inden for hans hørevidde. (Gaskell 315) ${ }^{1}$

Afbrydelser kan være afsløringer. I denne scene fra Elizabeth Gaskells Wives and Daughters (udgivet i Cornhill Magazine 1864-1866), viser Mrs Gibson tydeligt sin modvilje mod Roger Hamley, som ikke er rig nok til at være et passende parti for døtrene. Men afbrydelsen afslører også hjemmets tidslige politik. Visitter var socialt sanktionerede indtrængninger i dagligstuen, og kvinder forventedes at lægge deres gøremål fra sig og byde velkommen. Samtidig er Rogers besøg en vigtig del af det momentum, som driver bogens handling: Hans romantiske interesse i Cynthia eller Molly kan ændre deres fremtid. De små dagligdags foreteelser i stuen er derimod uden betydning og falder bort i det øjeblik, plottet, i form af den unge mand, træder ind gennem døren. Hverdagen, den banale gentagelse af små gøremål, bliver aldrig fortalt fyldestgørende - heller ikke i realistiske romaner, som Henry James ellers med en efterkommers

1 Alle oversættelser er mine egne, med mindre andet er angivet. 
arrogance kaldte "udflydende, posede monstre" (James 84). På sæt og vis bliver de trivielle aktiviteter i Mrs Gibsons dagligstue kun fortalt, fordi de bliver afbrudt. To slags tider bliver synlige i afbrydelsen: Plottets tid forstyrrer, og en porøs baggrundstid falder bort. Forudsætningen for udsigelse er afbrydelse.

Afbrydelsen optræder igen og igen i det nittende århundredes trykkekultur, ikke kun i romaner, men også i etikettelitteratur rettet mod kvinder. Det var en almenoplevelse, at kvinders tid i hjemmet var åben for afbrydelser. I denne artikel vil jeg analysere afbrydelsen i hjemmet som en kronotop i Bakhtinsk forstand: et almensted hvor tid og rum bliver synlige, eller en brudflade hvor forskellige tidslige lag mødes. Som Frank Trentman gør opmærksom på, så afslører afbrydelser "hverdagslivets elasticitet" og åbner for de politiske interesser, som også gemmer sig i hverdagen (Trentman 69).

Dynamikken mellem to tidslige lag bliver endnu mere synlig i et andet eksempel fra Wives and Daughters (som jeg undtagelsesvis må gengive på engelsk, eftersom de engelske verbaltider er afgørende for den kronopiske struktur):

One day, to Molly's infinite surprise, Mr Preston was announced as a caller. Mrs Gibson and she were sitting together in the drawing-room; Cynthia was out gone into the town a-shopping - when the door was opened, the name given, and in walked the young man. His entrance seemed to cause more confusion than Molly could well account for. [...] Mrs Gibson was at her everlasting worsted-work frame when Mr Preston entered the room; but somehow in rising to receive him, she threw down her basket of crewels, and, declining Molly's offer to help her, she would pick up all the reels herself, before she asked her visitor to sit down. $(224)^{2}$

Gaskell bruger to forskellige verbaltider i denne passage og opstiller der-

2 En dag blev hr. Preston meldt som gæst, til Mollys store overraskelse. Fru Gibson og hun sad i dagligstuen; Cynthia var ikke hjemme - hun var gået $\mathrm{i}$ byen for at handle - da døren blev åbnet, navnet blev meldt, og den unge mand trådte ind. Hans ankomst gav anledning til mere forvirring end Molly ville have forventet. [...] Fru Gibson sad ved sit evindelige uldbroderi da hr. Preston kom ind i rummet; men da hun rejste sig for at byde ham velkommen, kom hun på én eller anden måde til at tabe sin kurv med garn, og hun insisterede på at samle alle trisserne op selv, uden Mollys hjælp, før hun tilbød sin gæst at sidde ned. 
med en kontrast: Den udvidede tid ("were sitting" og "gone ... a-shopping") bruges om de kontinuerlige handlinger, det vil sige aktiviteter, som har udstrakthed. Dermed betegner udvidet tid en slags baggrundstid af ikke-plot, hvor banale ting sker nærmest $\mathrm{i}$ begivenhedsløshed. Verberne i simpel datid ("walked" og "entered") bruges derimod om handlinger, som afbryder denne baggrundstid. Gaskell opbygger hermed en relief-effekt, hvor de udstrakte aktiviteter (ikke-plot) falder i baggrunden, og de afbrydende handlinger (plot) træder i forgrunden. Ikke bare verbaltiderne, men hele udsigelsen signalerer denne kontrast mellem tidsligheder. Mr. Prestons bevægelse ind i rummet er beskrevet i korte og bestemte former: "the door was opened, the name given, and in walked the young man." Der sker her en acceleration i udsigelsen, som står i skarp kontrast til Mrs Gibsons håndarbejde, der beskrives som "everlasting." Resultatet er ikke bare en afbrydelse, men komplet forvirring. Forvirringen spejler dele af plottet, som hovedpersonen Molly endnu ikke har adgang til. Wives and Daughters handler om Molly Gibson, hvis far, som er landsbylæge og enkemand, gifter sig igen. Den nye stedmoder har en datter, Cynthia, og de kender Mr Preston fra deres fortid. Det viser sig, at både mor og datter har været fascineret af den farlige $\mathrm{Mr}$ Preston, noget som Mrs Gibson helst vil glemme. Samtidig ser Molly med uro, hvordan Roger Hamley (en dygtig ung videnskabsmand som Gaskell baserede på sin slægtning Charles Darwin), bliver forelsket i Cynthia. I scenen hvor Mr Preston ankommer, bruger Mrs Gibson forvirringen med uldgarnet til at skjule sin utilpashed over hans pludselige besøg. I denne scene er det altså ikke bare relief-virkningen mellem baggrundstid og forgrundstid, som kommer til syne, men også en skjult trussel om, at fortiden kan gribe forstyrrende ind i nutiden.

Når en ung mand afbryder en kedelig formiddag i Mrs Gibsons dagligstue, så afspejler den narrative fremstilling også en kønslig forståelse af tid og plot. Konventionen i den britiske domestiske roman er at forbinde mænd med plot, og kvinder med ikke-plot. Dette afspejler, at romanen det meste af århundredet domineres af det borgerlige ægteskabsplot. Denne konvention kræver en mand, som kan fri til den kvindelige hovedperson, og derfor udspiller kvinders liv på det centrale handlingsniveau i romanen sig ofte passivt afventende - som for eksempel Caroline Helstone i Charlotte Brontës Shirley (1849) eller Mary Thorne i Anthony Trollopes Doctor Thorne 
(1858). ${ }^{3}$ I praksis er den domestiske roman selvfølgelig ikke "plotløs", og ægteskabsplottet bliver udfordret i det nittende århundrede - især i romaner skrevet af kvinder. Psykosocial udvikling bliver i sig selv en større og større plotmotor i løbet af århundredet. Generelt bliver den domestiske roman centrum for en øget værdisætning af private og følelsesmæssige forhold, i modsætning til de store historiske udviklinger som kendetegnede for eksempel Walter Scotts romaner fra starten af århundredet. Fra Jane Austens Sense and Sensibility (1811) over Charlotte Brontës Wuthering Heights (1847) til George Eliots Middlemarch (1871-2) bliver individets livsvalg og emotionelle udvikling centrale for fortællingen. I store træk flytter plottet ind i hjemmet i 1800-tallet. ${ }^{4}$ Når det er sagt, så sker denne udvikling ikke uden konflikt. Selvom romaner i midten af 1800-tallet i højere grad giver kvinder kontrol over deres egen skæbne, så beskrives denne kontrol som noget, kvinder tilvrister sig, ofte forbundet med strid modstand fra deres omgivelser. I Gaskells Wives and Daughters kan Molly kun vente på, at Roger Hamley afslører, hvilken af de to stedsøstre han elsker, og hendes handlemuligheder er stærkt begrænsede.

Som et resultat af disse konventionelle plotstrukturer er det ikke usædvanligt at beskrive kvinders tid i hjemmet som afventende, udstrakt og udifferentieret. Den udvidede tid i Wives and Daughters kunne være symptomatisk for kvinders tid i viktoriansk kultur. Men jeg vil i denne artikel problematisere og uddybe den læsning ved at undersøge afbrydelsen som kronotop. Kronotoper kan ses som knudepunkter, hvor forskellige tidsligheder mødes, men afbrydelsen som kronotop fungerer også som en brudflade, hvor dynamikken mellem tidsligheder - eller mellem andre kronotoper - bliver synliggjort (Ladin 215, 220). Det faktum, at kvinders tid i hjemmet er åben for afbrydelse, er historisk, kulturelt og socialt betinget og er genstand for debat både i den realistiske roman og i den selvhjælpslitteratur, som i større og større omfang markedsføres til den voksende middelklasse. I både etikettelitteratur (med

3 Nina Auerbach argumenterer for, at tiden i Jane Austens Pride and Prejudice (1813) i høj grad går med, at kvinder venter på mænd; enten på, at en mandlig arving til Longbourn fødes, på et frieri fra en mand så en kvindes fremtid kan sikres, eller (mere indirekte) på, at Napoleonskrigene bliver afgjort (Auerbach 38).

4 For denne udvikling, se Nancy Armstrong; Chase and Levenson. 
titler som Home Truths for Home Peace), tidsskrifter (Reynolds's Miscellany) og romaner af Gaskell og Charles Dickens ser vi, at afbrydelsen bliver brugt som et greb til at fortælle udstrakt tid i hjemmet. Afbrydelse er et køns- og klassepolitisk problem, og Mikhail Bakhtins kronotopibegreb kan vise os, hvordan disse værdiladede tidslige lag konstrueres af teksten.

\section{KRONOTOPEN}

Kronotopen er et tekstligt greb, hvor tidslighed og rumlighed forenes. Bakhtin siger i sin indledning at:

I den skønlitterære kronotop sker der en sammensmeltning af de rumlige og tidsmæssige kendetegn i et meningsfyldt og konkret hele. Tiden fortættes, komprimeres og bliver her kunstnerisk-synlig; også rummet intensiveres og drages ind $\mathrm{i}$ tidens, plottets og historiens bevægelse. Tidens kendetegn udfoldes i rummet, og rummet fyldes med mening og dimension af tiden. $(13)^{5}$

Kronotopen får tiden til at udtrykke sig i rummet; der sker altså en konkretisering, hvor tiden "iklædes kød og blod i kronotopen" (167). Konkretiseringen handler i høj grad om at stille tiden (og i mindre grad rummet) til rådighed for en symbolanalyse. I den kunstneriske forestillingskraft, siger Bakhtin, kan tid og rum ikke tænkes som abstrakte størrelser, men er "indbyrdes uadskillelige og altid emotionelt-værdimæssigt farve[de]" (161). I den kreative tilblivelse af et litterært værk, men også i mødet mellem et værk og en aktiv læser, skabes værkets tids- og rumforhold (170). Ligesom Paul Ricœur forestiller Bakhtin sig udvekslingen mellem værk og verden som en mimetisk cirkel, hvor værkets diegetiske tidsoplevelse både opstår fra, og vender tilbage til, den virkelige verdens tidsoplevelse (Bakhtin 171; Ricœur 50-71). På den baggrund læser jeg kronotopen, som bestående ikke blot af tid og rum, men også af et tredje element: udsigelse. Som overbygning til Bakhtins konkretisering arbejder jeg med kronotopens konceptualisering af tid. Konceptualisering gør netop abstrakte forhold tilgængelige for symbollæsninger; både kronotoper og symboler er på sin vis fortætninger. I kronotopen interagerer forskellige andre tidsligheder eller 
kronotoper (eventyrtid, historisk tid, cyklisk tid, biografisk tid, biologisk tid osv.) og indgår i et komplekst og dialogisk felt.

Bakhtins kronotopiteori er vidtfavnende, og han bruger ordet både som et genrebegreb (hvor værkets genre afgøres af en overordnet kronotop), om epoke-kronotoper i historisk forstand, og helt ned til tegnets niveau. Disse niveauspring kan både være forvirrende og produktive, og de er udmærket beskrevet andetsteds (Ladin; Schmidt; Renfrew). I denne artikel vil jeg beskæftige mig mest med det sidste afsnit i "Tidens og kronotopens former i romanen." Dette afsnit tilføjede Bakhtin i 1973, og det omhandler blandt andet det, som Rigmor Kappel Schmidt kalder "delkronotoper" (Schmidt 86-89). Det er her, Bakhtin taler om vejen, tærsklen og salonen som vigtige kronotoper, og det er her, kronotopibegrebet kommer tættest på de "almensteder", som topologien mere bredt interesserer sig for.

Delkronopen er et almensted, som giver os den konkretisering, der skal til for overhovedet at tale om tid. I de to små episoder fra Gaskells Wives and Daughters bliver udsigelsesniveauet brugt til at skabe en reliefvirkning mellem to tidsligheder eller kronotoper: en forgrundstid hvor plottet skubbes fremad (en ung mand ankommer og fungerer som katalysator), og en baggrundstid som er handlingstom og let at afbryde. ${ }^{6}$ Samtidig må vi spørge os selv om baggrundstiden overhovedet ville være blevet fortalt, hvis ikke det netop var for afbrydelsen. Scenen skal sættes, personerne skal placeres, og vi skal forstå den tidslighed, som forsvinder, når plottet tager over. Baggrundstiden fortælles altså kun i det øjeblik, den falder bort - dens negering er forudsætning for dens udsigelse. Denne baggrundstid kalder jeg "hjemmets tid", og denne artikel handler om afbrydelsen som synliggørelse - og dermed en udsigelsesmulighed som konceptualierer hjemmets tid. Delkronotopen er, ligesom almenstedet i mere bred forstand, et møde mellem en materiel historisk virkelighed og tekstens narrative funktioner og genretræk.

6 Man skal huske, som Eder o.a. pointerer, at personlighed og mentale processer også sagtens kan være "plot" eller skubbe plottet fremad. Det er dermed ikke eviggyldigt, at plot sidestilles med fysiske handlinger, men en funktion af den type fiktion (eller kronotop) der arbejdes med (Eder o.a., 22). Samtidig skal det understreges, at netop Gaskell arbejder med psykologisk tid som en langsom men sikker plotkatalysator; se Damkjær; Haugtved. 
Jeg forstår ikke hjemmets tidslighed som et fokuspunkt i 1800-tallets roman, men som en slags bitid. Bakhtin beskriver meget præcist, hvordan sådan en bitid produceres og værdisættes i modsætning til plottets tid, og derfor er det værd at citere en længere passage fra "Tidens og kronotopens former." Her taler Bakhtin om provinsiel tid, en tidslighed som han blandt andet finder i Flauberts romaner:

Her findes ingen begivenheder, der findes udelukkende gentagne 'vanskeligheder'. Tiden er her berøvet fremadskridende historisk gang, den bevæger sig i snævre cirkler: dagens cirkel, ugens og månedens cirkel, hele livets cirkel. [...] Dag ud og dag ind gentages de samme hverdagshandlinger, de samme samtaleemner, de samme ord. [...] Det er den banale og trivielle cykliske hverdagstid. [...] Denne tids kendetegn er enkle og robust-materielle, og de er smeltet solidt sammen med hverdagens lokaliteter: med købstadens små huse og trange dagligstuer, med de søvnige gader, med støvet og fluerne, med klubberne og billardbordene og så fremdeles. Tiden her er begivenhedsløs og synes derfor næsten at være gået i stå. [...] Det er en tyktflydende og klæbrig tid, som snegler sig gennem rummet. Derfor kan den ikke være hovedtiden i en roman. Den bruges af romanforfattere som en bitid, den væves sammen med andre, ikke-cykliske tidsrækker eller afbrydes af dem, og ofte fungerer den som en kontrasterende baggrund for begivenhedsrige og energetiske tidsrækker. (165-6)

Denne "tyktflydende og klæbrig[e] tid" opstår, vil jeg påstå, som en kontrast til det nittende århundredes mest dominerende modernitetsforståelser. Modernitet i 1800-tallets romaner blev associeret med handling, udvikling, forandringer og mobilitet (Berman). Moderniteten negerer den provinsielle tid, som dermed bliver fremstillet som "begivenhedsløs." Skønt Bakhtin siger, at romanforfattere "bruger" den provinsielle tid som en bitid, så mener jeg, at det er mere præcist at sige, at Flauberts romaner producerer deres bitid i samme nu, som udsigelsen væver de mere dynamiske, begivenhedsrige tidsligheder - de dramatiske eller følelsesmæssige dele af plottet. Den realistiske roman lever i høj grad af modsætningen mellem stagnation og udvikling. Det moderne skal have noget at reagere imod: Baggrunden ville ikke eksistere, hvis plottet ikke gjorde. Med andre ord, så er begivenhedsløshed en (utilsigtet) konstruktion af udsigelsen i lige så høj grad som begivenhed. Begivenhedsløshed er en ledsagetid. På samme måde kræver Mr Prestons afbrydelse, at han har noget at afbryde; den hjemlige bitid beskrives i samme nu, som den falder bort. 
180 KULTUR \& KLASSE * $123 * 2017$

TOPOLOGI

Det siger sig selv, at forskellige forfattere udtrykker denne kontrast på deres egen måde, og nogle forfattere konstruerer slet ikke en baggrundstid i deres fremstilling af middelklassehjemmet. Anthony Trollope, der strukturerer sine romaner omkring en stærk autorialfortæller, opbygger næsten aldrig en sådan reliefeffekt; Trollope er ikke synderlig interesseret i det specifikke øjeblik og rum, hvor en samtale finder sted, og hans håndværk præges mere af "telling" end af "showing." I Gaskells værker derimod, og især i Wives and Daughters, er alle hændelser og samtaler situeret i tid og rum: Denne situering er faktisk ofte afgørende for plottets udvikling. Det er det, som Kappel Schmidt kalder "forankring" (80), hvor det enkelte steds specificitet har betydning. I kapitel 51, hvor døtrene Molly og Cynthia får nyheden fra en tjenestepige om, at en vigtig person er død, står de to kvinder sammen i faderens modtageværelse, hvorfor Mrs Gibson ikke hører nyheden med det samme. Det lykkes derfor Molly at handle uden indblanding fra sin overfladiske stedmor, og yde vigtig hjælp til de efterladte i deres sorg - vigtig fordi Molly kender hemmeligheder, som nu skal frem i lyset. Wives and Daughters handler i det hele taget om cirkulering af information (hemmeligheder, rygter og halve sandheder), og tilfældige placeringer i rum og tid er afgørende for, hvem der får adgang til hvilken information.

Kontrasten mellem kronotoper i Gaskells roman går langt videre end baggrundstid og plottid - baggrundstid kan også afbrydes af følelsesmæssige og spirituelle perspektiver, som her tidligt i romanen:

Dag efter dag blev disse småbanale gøremål afbrudt af nyheder [om] hvordan fru Hamley gradvist nærmede sig døden. Molly - som ofte sad ved siden af Cynthia, omgivet af bånd, og ståltråd, og tyl - hørte bulletinerne som en begravelsesklokke til en bryllupsfest. (218)

Her er det døden - forbundet med både endelighed og med uendelighed i den kristne lære - som bryder ind i hverdagens banaliteter som en rungende klokke. Afbrydelsen bliver iterativ, og knyttes på den måde tæt ind i hverdagslivet. Afbrydelsen er en psykologisk ladet oplevelse for Molly, men som Gaskells hovedperson er hun også forankret i tids- og steds-specificitet. I Wives and Daughters dramatiserer Gaskell almenoplevelsen af, at afbrydelser synliggør forskellige kronotoper og deres indbyrdes værdiforhold. 


\section{KVINDERS PORØSE TID}

Bakhtins kronotopiske bitid, og den måde den produceres i Gaskells roman, åbner et helt centralt perspektiv: at kronotopens konceptualisering strækker repræsentationen, så det skjulte og uformelige gives form. Udsigelsens produktion af bitid kan forstås som en konstruktiv marginalisering af ét tidsligt lag til fordel for at andet. Marginaliseringen er netop konstruktiv, fordi den tillader repræsentation af en kronotop, som ellers aldrig fortælles; hjemmets baggrundstid bliver narrativt mulig i det øjeblik, den falder bort. Den viktorianske realistiske romantradition kredsede omkring spørgsmålet - hvor mange detaljer kan man fortælle før romanen bliver overlæsset og plottet afspores? Hvor meget håndarbejde, hvor mange stille læsestunder, hvor mange måltider kan nævnes? (Mucignat 44; Shrimpton). Som Roland Barthes beskriver det i sin artikel om virkelighedseffekten, så har den overflødige men velplacerede detalje til opgave at signalere "virkelighed." Detaljerigdom er, ifølge Barthes, et tegn, som skal henvise til virkelighedens overflod af ting (Barthes 146-148). Detaljens utilsigtede og forbigående udsigelse (i dét den falder bort), er et udtryk for, at udsigelsesmuligheden strækkes.

Middelklassehjemmet er kun ét sted - men et vigtigt sted - hvor denne narrative problematik udspiller sig i litteraturhistorien. I et historisk perspektiv dramatiserer afbrydelsen også en udbredt dynamik, nemlig at hjemmets tid, og specifikt kvinders tid i hjemmet, var porøs. Det var almindeligt at opfatte kvinders tid som vigende og mænds tid som dominerende. Denne kønspolitiske dynamik kan ikke reduceres til en dikotomi mellem mandlig "lineær" tid og kvindelig "cyklisk" tid - en læsning som Julia Kristeva har betegnet som essentialistisk i sit vigtige essay om kvinders tid:

Ved at kræve anerkendelsen af en irreduktibel identitet, uden lige hos det andet køn, og udfoldet som sådan, flertallig, flydende, ikke-identisk på en måde, placerer denne feminisme sig uden for the lineære tid, hvor identiteter kommunikerer via projektioner og krav; på den ene side forbinder den sig igen med en arkaisk (mytisk) hukommelse og, på den anden side, med de 'marginaliseredes' cykliske eller monumentale tid. $(279)^{7}$ 
182 KULTUR \& KLASSE * $123 * 2017$

TOPOLOGI

En feminisme, som insisterer på, at kvinders tid er uforenelig med mænds tid, foretager en mytologisering, mener Kristeva. Denne dikotomi må problematiseres, for det er langt vigtigere at spørge, hvordan disse monumentale modsætninger konstrueres gennem narrative strategier. Når man argumenterer for, at kvinders tid i det nittende århundrede var decideret ufortællelig indenfor lineær tid og bedre kan forstås som cyklisk, så har man accepteret en række kønspolitiske værdiladninger, som ikke er naturgivne. ${ }^{8} \mathrm{Hjemmets}$ tid som kronotop er netop ikke historieløs eller uproduktiv, ej heller er den plotfremmed. Hjemmets tid producerer bare handling og karakterudvikling i et andet tempo, end de mere dramatiske plotstrenge gør det. ${ }^{9}$

Gaskells roman er en del af en større kulturhistorisk udforskning af tid og af kronotopiske dynamikker. Hjemmets tid, hvordan den føltes, og hvordan man bedst udnyttede den, blev behandlet direkte eller indirekte i en lang række tekster - romaner, digte og noveller, men også rådgivningslitteratur. Romanens sejrsgang skal ses i lyset af en eksplosion $i$ alle former for tryk, drevet frem af ny trykketeknologi, sænkede (og efterhånden afskaffede) afgifter på papir og nyheder, og en voldsom stigning i købekraft hos den voksende middelklasse. Der blev produceret mere og mere tekst: aviser, tidsskrifter, videnskabelige udgivelser, historie, skuespil, musik, encyklopædier, selvhjælpsbøger og husholdningsmanualer, for at nævne nogle af genrerne. Den realistiske roman er bare ét udtryk for en omsiggribende beskrivelsestrang. ${ }^{10}$ Middelklassens fremvækst kaldte - blandt andet - på skriftlige indføringer $\mathrm{i}$, hvordan bourgeoisiets hjem skulle føres, og mange udgivelser skrev sig selv ind i en opdragelsesopgave. I krydsfeltet mellem beskrivelsestrang og opdragelsesopgave - som producerede et enormt deskriptivt og normativt felt - ser vi blandt andet en øget konceptualisering af hjemmets tidslighed. I en bog fra 1860, skrevet af Henrietta Wilson, bliver middelklassekvindens arbejde med at styre husholdningen sammenlignet med et urværk:

8 En sådan misforstået adskillelse mellem mænds og kvinders tid sker for eksempel i Ermarth, især kapitel 4.

9 Gaskells romaner insisterer ofte på, at mennesker har brug for tid til at udvikle sig. Se Damkjær 98-103.

Se Broomfield; Chase and Levenson; Mucignat. 
Giv dine ordrer på samme tid hver dag, giv ordrerne så tidligt på dagen som muligt, forklar dine ønsker tydeligt, og lad så vidt som muligt en enkelt optrækning af hjemmets ur være tilstrækkeligt for én dag. Hverken ure eller husholdninger går godt hvis de konstant bliver pillet ved, afbrudt, og ændret i forhold til tid. (Wilson 112)

Metaforen om hjemmet som ur - en mekanisme som dybest set tilbagelægger præcis samme strækning dag efter dag, med de samme handlinger i evig gentagelse - er uhyre tiltrækkende. Den giver en følelse af, at arbejdet kan gentages og hjemmets status opretholdes i uforanderlighed. Men under periodens beskrivelsestrang bliver det umuligt at opretholde dette behageligt enkle billede. Hjemmets tid modsætter sig skemalægning, ${ }^{11}$ især når den udsættes for det nittende århundredes stærkt detaljeorienterede trykkekultur. Selv Charles Dickens, hvis værker i høj grad benytter sig af gentagelse, må i sin sidste afsluttede roman konstatere, at hvis hjemmets tid sættes på skema, så bliver resultatet et monster - her Mr Podsnap i Our Mutual Friend (1864-1865):

Verden stod op klokken otte, barberede sig kvart over, spiste morgenmad klokken ni, tog på kontoret klokken ti, kom hjem halv seks, og spiste middag klokken syv. Hr. Podsnaps idéer om De Skønne Kunster i deres helhed kunne opsummeres således. Litteratur; store typer, beskrivelser af at stå op klokken otte, barbere sig kvart over, spise morgenmad klokken ni, tage på kontoret klokken ti, komme hjem halv seks, og spise middag klokken syv. [...] Intet andet skulle tillades disse vagabondiske Kunstarter, og straffen for overtrædelser skulle være bandlysning. Intet andet skulle være tilladt - nogen steder!" (Dickens, Our Mutual Friend 128-9)

Mr Podsnaps skema er et tegn på erfaringstomhed, og som noget nyt i Dickens' værker overføres denne følelse til hjemmet. Our Mutual Friend er en af hans eneste romaner, hvor heltinden (her Bella Wilfer) får lov til at øve sig på husholdningsarbejdet, og rent faktisk laver fejl i begyndelsen. I hverdagens verden er skemaer bare abstraktioner uden tilfældigheder, forsinkelser, eller middagsretter som brænder på. Urværksmetaforen udelukker den levede tids uregelmæssigheder.

11 Socialhistorikeren Joakim Voth må opgive at kvantificere husligt arbejde i perioden, fordi det er en "skønssag." (Voth 82). 
184 KULTUR \& KLASSE * $123 * 2017$

TOPOLOGI

\section{FLYDENDE TID: STRUKTUR OG AFBRYDELSE}

Evig gentagelse fungerer ikke, hverken i den realistiske roman eller i de praktiske beskrivelser i manualerne. Rådgivningslitteraturen afspejler da også, at urværksmetaforen havde alvorlige mangler, især i lyset af den porøse tidslighed, som kvinder levede i. Som en vis M.B.H. skrev i bogen Home Truths for Home Peace i 1851:

På tusinde uventede måder må den gode hustru og moder forvente at blive afbrudt, og hun vil sikkert underkaste sig disse afbrydelser mere beredvilligt hvis hun betragter dem som en vigtig del af dagens arbejde [...]. Og lad hende ikke glemme hvilken hæder og hvilket privilegium det er hele tiden at være efterspurgt og ombejlet. (83-4)

Når M.B.H. understreger, hvilken ære det er at være efterspurgt konstant af hele familien og husholdingen, så er det selvfølgelig et forsøg på at omkode en problematisk ubalance mellem kønnene til noget positivt. ${ }^{12}$ Selv om nogle forfattere insisterede på at skemalægge hjemmets tid, så måtte de som regel indse, at hjemmet kun kunne fungere i praksis, hvis husholdersken var omstillingsparat.

Den narrative marginalisering i Wives and Daughters og andre realistiske romaner reflekterer altså en større kulturhistorisk oplevelse af kontrasterende tidsligheder og kønspolitiske forhandlinger i hjemmet. Spørgsmålet er: Hvordan kan man beskrive en flydende tidslighed, så den fungerer normativt indenfor klasse-og kønsbegreberne; med andre ord, hvordan kan den naturaliseres? Dette spørgsmål hænger sammen med et andet: Hvordan kan udsigelsen bruges til at synliggøre noget af det sværeste at fortælle, nemlig tid? Én løsning på problemet kan findes i en kort artikel med titlen "Spare Moments," skrevet af Anna Ritchie og trykt i Reynolds's Miscellany i 1859. Artiklen handler om, hvordan tiloversbleven tid - "spare moments" - kan gøres produktiv i dagligdagen. Her beskrives en idealiseret husmoder ved navn Mabel, som aldrig virker fortravlet eller uforberedt:

12 Både Florence Nightingale og John Stuart Mill skrev modsvar til denne ideologi, Nightingale i den privat-udgivne Cassandra i 1860 og Mill i The Subjection of Women i 1869 (Nightingale 67-72; Mill 137-9). Begge understregede det uretfærdige i, at kvinders tid ikke var deres egen, men at de altid måtte stå til rådighed. 
[Hemmeligheden bag god husførelse] lå i Mabels brug af sine tiloversblevne øjeblikke - små rester af tid - mellemrum mellem planlagte begivenheder - pauser som folk som regel lader falde bort uden at udnytte dem, mens de venter på det som skal til at ske - at blive kaldt til et forsinket måltid - en vens sene ankomst en nølende karet - på at regnen skal holde op - eller hundrede lignende daglige hændelser. (398)

Ritchie beskriver spildtid for at opfordre sine læsere til at mobilisere deres "spare moments", som Mabel gør det. Hun prøver at omkode en daglig irritation i læsernes hverdag til et potentiale; al tid kan instrumentaliseres. Men i udsigelsen sker der det besynderlige, at sætningen selv bliver forsinket: Ritchie tilføjer sætningsled efter sætningsled, adskilt fra hinanden med tankestreger. I en slags ekko af det, som beskrives, bliver sætningen mere og mere vævende og mister til sidst grammatisk fokus. Ligesom en uheldig husholderske, så mister forfatteren grebet om opgaven; sætningen løber ud i sandet. Således manipulerer Ritchie realismens virkemidler for at beskrive de mange afbrydelser og afvigelser, som hjemmets tid bliver udsat for. Selv i halvdårlige sætningskonstruktioner i banale selvhjælpsartikler ser vi altså en trang til at strække udsigelsens potentiale. Detaljerne - det forsinkede måltid, den uønskede regn - står, ligesom Barthes' luksuriøse detaljer, for et liv fuldt af konkrete hændelser, som aldrig kan fortælles fyldestgørende. Bitiden, som i den realistiske roman er narrativt marginaliseret, kan i rådgivningslitteratur - og i øvrigt i didaktisk litteratur - gøres til central plottid. Ritchies vævende sætning er et forsøg på at konceptualisere en tidsoplevelse, som er flydende, porøs og fuld af forsinkelser og afbrydelser.

\section{DEN YDERSTE MARGIN: TJENESTEFOLK}

Narrativ marginalisering skaber et dynamisk samspil mellem center og periferi - en reliefeffekt, som antyder en bagvedliggende, fortløbende kronotop i hjemmet. Sagt med andre ord: Afbrydelser er nødvendige for at give dybde og dynamik til repræsentationen, men de afslører også et hierarki af mere eller mindre marginaliserede tidslige lag. Og den mest ekstreme narrative marginalisering i den realistiske roman er marginaliseringen af tjenestefolk. I almenstedet bliver ikke bare kønspolitiske, men også klassepolitiske linjer trukket op. Når hjemmets tid bliver afbrudt, og 
186 KULTUR \& KLASSE * $123 * 2017$

TOPOLOGI

kronotopernes brudflader mødes, så er det tit tjenestepigen - en næsten usynlig person - som rent fysisk står for at forstyrre. Som Bruce Robbins har pointeret:

Tjenestefolk [i det nittende århundredes roman] kom til at repræsentere selve det, som ikke kunne repræsenteres: Tilstedeværelsen af tjenestefolk betød fraværet af menneskene. Som vejskilte, efterladt tilfældige steder i det ingenmandsland, der ligger mellem, hvad der kan, og hvad der ikke kan repræsenteres, markerer de blot, at den anden side af grænsen er befolket. (Robbins 27)

Som Robbins gør klart, så hører tjenestefolk til i den gruppe af detaljer som er allestedsnærværende, men narrativt marginaliserede. I citatet fra Wives and Daughters, som jeg analyserede ovenfor, optrådte der en usynlig tjenestepige: "the door was opened, the name given, and in walked the young man" (224). Ingen bemærker eller husker denne person, som kun registreres i narrativet gennem sine fysiske handlinger: Hun åbner en dør og siger et navn. Men det er tjenestepigen, som faciliterer afbrydelsen: Det er hende, som fungerer som bindeled mellem ude og inde; det er hende (eller en kollega), som bringer nyheden om dødsfaldet i kapitel 51. I øvrigt blev hendes forgænger fyret for at smugle kærlighedsbreve for en forelsket lægeelev - endnu en vigtig plotfunktion som kræver en tjenestepige som mellemled. Hendes hånd på dørhåndtaget, hendes stemme, hendes mediering af plottet, er alt sammen utilsigtede detaljer, som ligger på kanten af det repræsentérbare. Tjenestepigen er afbrydelsen, eller rettere, hun er mellemled for afbrydelsen - et mellemled som yder så minimal friktion, at hendes tilstedeværelse er reduceret til næsten ingenting.

Som plotmekanisk element er tjenestefolk uovertrufne, men meget sjældent tredimensionelle karakterer. I Charles Dickens' Bleak House (18521853) er næsten hele personalet navnløst. Ofte optræder tjenestefolkene i huset indirekte, med henvisning til deres aktiviteter og stemmer: "man kunne høre hestene blive striglet udenfor stalden, og de fik besked på at Passe på, og Flytte sig, når de gled på de ujævne brosten" (Dickens 79). Selv om de to udråb teknisk set er direkte tale, så er de ikke angivet med anførselstegn. Nogle gange hører man ikke engang stemmer, men bare fjerne lyde af arbejde: en "hyggelig klirren i baggrunden, som var forbundet med middagsforberedelserne" (80). Disse auditive tegn på beboelse er med til at 
give Bleak House en dybde i repræsentationen, men de repræsenterer også en bagvedliggende tidslighed. Hverdagstid består trods alt af den praksis - de fysiske handlinger - som opretholder hjemmet (Shove 17). Dette er teknisk set ikke en afbrydelse, men en slags auditiv sammenfletning af forskellige kronotoper. Med andre ord, så konceptualiserer disse baggrundslyde Bleak Houses tidslighed. Udsigelsessituationen i romanen gør, at denne tidslighed fremstår utilsigtet: med andre ord, en klassisk bitids-kronotop i Bakhtinsk forstand. Dermed antydes det, at den kronotop, som får Bleak House til at hænge sammen - som sørger for mad på bordet, redte senge og raske heste fortsætter, selv når den ikke bliver fortalt, og selv når den ikke styres af husets frue. Bleak House bruger vage henvisninger til tjenestefolk og deres arbejde til at antyde en rumlig-temporal udstrækning, som aldrig beskrives direkte. Tjenestefolkene antyder, med Robbins' ord, at den anden side af grænsen er befolket. Hjemmet er en fortløbende, dynamisk, men narrativt lavproduktiv kronotop i sig selv. I afbrydelsen dukker hjemmets tid frem i kanten af det narrative synsfelt og peger på tidslige oplevelser uden for plottet.

Almensteder er ikke statiske: De er i konstant udvikling, fortælleteknisk og socialt. Almensteder er netop møder mellem genkendelighed og genforhandling. Derfor kan en nyhistoristisk analyse af afbrydelsen afsløre de lag af social marginalisering, som giver dybde til fortællingen. I det nittende århundrede havde den realistiske roman, men også etikette- og selvhjælpslitteraturen, et behov for at beskrive og retfærdiggøre afbrydelse. Afbrydelsen i hjemmet, som den fremstilles i trykkekulturen, viser de værdiforhandlinger, som altid spiller med i konceptualiseringen. Denne artikel har argumenteret for et fokus på topologiens kanter, marginer og grænseflader. På grænsen mellem hvad der kan og ikke kan fortælles, på kanten af det repræsenterbare, dramatiserer disse tekster et møde mellem forskellige tidsligheder, og udsætter dermed hjemmets tid for en kritisk analyse. Det næsten ufortællelige dukker frem i kanten af repræsentationen; afbrydelsens kronotop synliggør det usynlige. 
188 KULTUR \& KLASSE * $123 * 2017$

TOPOLOGI

Denne artikel indeholder materiale fra min bog, Time, Domesticity and Print Culture in Nineteenth-Century Britain (Palgrave Macmillan, 2016), og jeg vil gerne takke Palgrave Macmillan for tilladelse til at reproducere materialet her.

\section{INTERRUPTION, THE CHRONOTOPE AND}

BRITISH LITERATURE, 1840-1870

Bakhtin's chronotope is not only a meeting between time and space, but often also a meeting between a number of contrasting temporalities. This article discusses the topos of domestic interruption, which lays bare the temporal politics of the nineteenth-century middle-class home. It was a commonplace in the nineteenth century that women's time in the home was interruptible and porous. When Victorian writers described everyday interruptions, they showed the contrast between plot time and an underlying marginalised domestic time. In an analysis of Elizabeth Gaskell's Wives and Daughters (1864-1866), combined with a new historicist reading of Victorian advice literature, this article argues that narrative marginalisation was paradoxically a viable strategy for showing an otherwise invisible temporality. In the background, peeping out whenever the plot interrupts, is an enduring and ongoing time, mediated by unnamed and underrepresented servants, that gives the middle-class home temporal depth and realism.

\section{KEYWORDS}

EN: Elizabeth Gaskell, Charles Dickens, British, Victorian time, chronotope, Mikhail Bakhtin, realism, women, class, servants

DA: Elizabeth Gaskell, Charles Dickens, britisk, viktoriansk tid, kronotop, Mikhail Bakhtin, realisme, kvinder, klasse, tjenestefolk

\section{LITTERATUR}

Armstrong, Nancy. Desire and Domestic Fiction: A Political History of the Novel. New York og Oxford: Oxford University Press, 1989.

Auerbach, Nina. Communities of Women: An Idea in Fiction. Cambridge, Mass. og London: Harvard University Press, 1978. 
Bakhtin, Mikhail. "Tidens og kronotopens former i romanen: Essay om historisk poetik." Oversat af Harald Hartvig Jepsen. Rum, tid \& historie: Kronotopens former i europæisk litteratur. Århus: Klim, 2006. 11-175.

Barthes, Roland. "The Reality Effect." Roland Barthes. The Rustle of Language. Oversat af Richard Howard. Berkeley og Los Angeles: University of California Press, 1989. 141-148.

Berman, Marshall. All that is Solid Melts Into Air. New York: Penguin, 1988.

Broomfield, Andrea. Food and Cooking in Victorian England: A History. Westport og London: Praeger, 2007.

Chase, Karen og Michael Levenson. The Spectacle of Intimacy: A Public Life for the Victorian Family. Princeton og Oxford: Princeton University Press, 2000.

Damkjær, Maria. Time, Domesticity and Print Culture in Nineteenth-Century Britain. Basingstoke og New York: Routledge, 2016.

Dickens, Charles. Bleak House. Red. Stephen Gill. Oxford World's Classics. London og Oxford: Oxford University Press, 2008.

Dickens, Charles. Our Mutual Friend. Red. Michael Cotsell. Oxford World's Classics. Oxford: Oxford University Press, 2008.

Eder, Jens, Fotis Jannidis og Ralf Schneider. "Characters in Fictional Worlds: An Introduction." Characters in Fictional Worlds: Understanding Imaginary Beings in Literature, Film, and Other Media. Red. Jens Eder, Fotis Jannidis og Ralf Schneider. Berlin: De Gruyter, 2010. 3-64.

Ermarth, Elizabeth Deeds. The English Novel in History, 1840-1895. London og New York: Routledge, 1997.

Gaskell, Elizabeth. Wives and Daughters. Red. Pam Morris. London: Penguin, 2003.

Haugtvedt, Erica. "The Sympathy of Suspense: Gaskell and Braddon's Slow and Fast Sensation Fiction in Family Magazines." Victorian Periodicals Review. 49.1 (Spring 2016): 149-170.

James, Henry. The Art of the Novel: Critical Prefaces. Boston: Northeaster University Press, 1984.

Kristeva, Julia. "Kvindetid." Køn og Moderne Tider: En Antologi. Red. Marie-Louise Svane og Tania Ørum. Oversat af Lis Haugaard. København: Tiderne Skifter, 1991, 271-300.

Ladin, Jay. "Fleshing Out the Chronotope." Critical Essays on Bakhtin. Red. Caryl Emerson. New York: G.K. Hall, 1999. 212-236.

"M.B.H." Home Truths for Home Peace, Or, Muddle Defeated: A Practical Inquiry into what Chiefly Mars or Makes the Comfort of Domestic Life. Especially Adressed to Young Housewives. London: Effingham Wilson, 1851.

Mill, John Stuart. The Subjection of Women. 2. udg. London: Longmans, Green, Reader, and Dyer, 1869.

Mucignat, Rosa. Realism and Space in the Novel, 1795-1869. Farnham: Ashgate, 2013.

Nightingale, Florence. Cassandra and Other Selections from Suggestions for Thought. Red. Mary Poovey. London: Pickering and Chatto, 1991.

Renfrew, Alastair. Mikhail Bakhtin. Routledge Critical Thinkers. London og New York: Routledge, 2015. 
Ricœur, Paul. Time and Narrative, bind 1. Oversat af Kathleen McLaughlin og David Pellauer. Chicago og London: University of Chicago Press, 1984.

Ritchie, Anna. "Spare Moments." Reynold's Miscellany of Romance, General Literature, Science, and Art. 17. december, 1859. 398.

Robbins, Bruce. The Servant's Hand: English Fiction from Below. New York: Columbia University Press, 1986.

Schmidt, Rigmor Kappel. Bakhtin og Don Quixote: En indføring i Mikhail M. Bakhtins univers. Aarhus: Klim, 2003.

Shove, Elizabeth. "Everyday Practice and the Production and Consumption of Time." Time, Consumption and Everyday Life: Practice, Materiality and Culture. Red. Elizabeth Shove, Frank Trentmann og Richard Wilk. Oxford og New York: Berg, 2009. 17-33.

Shrimpton, Nicholas. "Bric-à-Brac or Architectonicè? Fragment and Form in Victorian Literature." Literary Bric-à-Brac and the Victorians: From Commodities to Oddities. Red. Jonathon Shears og Jen Harrison. Farnham: Ashgate, 2013. 17-32.

Trentman, Frank. "Disruption is Normal: Blackouts, Breakdowns and the Elasticity of Everyday Life." Time, Consumption and Everyday Life: Practice, Materiality and Culture. Red. Elizabeth Shove, Frank Trentmann og Richard Wilk. Oxford og New York: Berg, 2009. 67-84.

Voth, Hans-Joachim. Time and Work in England:1750-1830. Oxford: Clarendon Press, 2000.

Wilson, H. [Henrietta]. Homely Hints from the Fireside. 2. udg. Edinburgh: Edmonston and Douglas, 1860. 